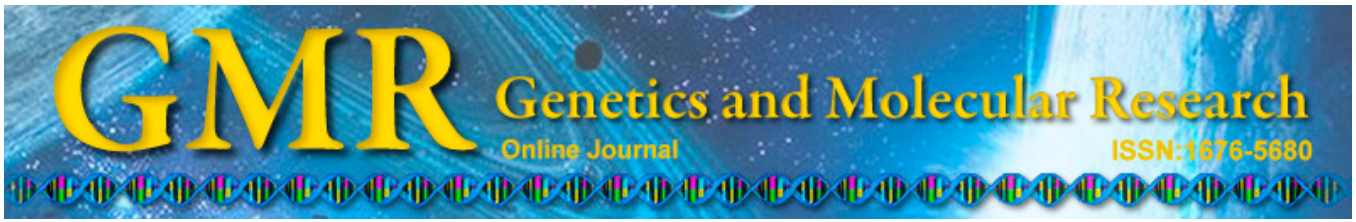

Short Communication

\title{
Screening of basidiomycetes in submerged cultivation based on antioxidant activity
}

\author{
S.H. Umeo, G.P.N. Souza, P.M. Rapachi, D.M. Garcia, \\ L.D. Paccola-Meirelles, J.S. Valle, N.B. Colauto and G.A. Linde \\ Pós-Graduação em Biotecnologia Aplicada à Agricultura, \\ Universidade Paranaense, Umuarama, PR, Brasil \\ Corresponding author: J.S. Valle \\ E-mail: jsvalle@unipar.br \\ Genet. Mol. Res. 14 (3): 9907-9914 (2015) \\ Received February 13, 2015 \\ Accepted July 1, 2015 \\ Published August 19, 2015 \\ DOI http://dx.doi.org/10.4238/2015.August.19.25
}

\begin{abstract}
Submerged cultivation of medicinal basidiomycetes is a reproducible and efficient method of producing mycelia and metabolites. The antioxidant activity indicates its medicinal properties and is an important tool for basidiomycete screening. In this study, we analyzed the production of mycelial biomass and exopolysaccharides and the antioxidant activity of basidiomycete strains in submerged cultivation. Twenty-five strains were used for submerged cultivation in extract malt medium, and the production of mycelial biomass and exopolysaccharides was evaluated. Antioxidant activity was determined using the 1,1-diphenyl-2-picrylhydrazyl method. Among the 25 evaluated strains, Lentinus crinitus produced the highest biomass, reaching $1190 \pm 52 \mathrm{mg} \cdot \mathrm{L}^{-1}$ day $^{-1}$; Agaricus subrufescens strains had the highest exopolysaccharide production from $18.96 \pm 0.15$ to $20.97 \pm$ $2.10 \mathrm{mg} \mathrm{L}{ }^{-1}$. day ${ }^{-1}$. Additionally, A. subrufescens showed the highest total antioxidant activity, reinforcing the therapeutic potential of this basidiomycete. No significant correlation was found between mycelial biomass or exopolysaccharide production and antioxidant activity;
\end{abstract}


however, the results depended on each species and the strains of the same species. We found large variations in the production of mycelial biomass and exopolysaccharides and in antioxidant activity among different species and among strains of the same species. Thus, evaluating the total antioxidant activity is an important tool for identifying strains with biotechnological potential.

Key words: Agaricus blazei; Agaricus brasiliensis; Lentinula edodes; Lentinus crinitus; Pleurotus ostreatus; Schizophyllum commune

\section{INTRODUCTION}

The fungus kingdom includes approximately 1.5 million species; however only 14,000 are basidiomycetes (Blackwell, 2011). Few of these genera are cultivated on an industrial scale worldwide, including Pleurotus, Lentinula, Auricularia, Agaricus, Flammulina, Coprinus, Agrocybe, and Volvariella (Li, 2012). Mushrooms are used for a variety of biotechnological applications, particularly for the production of food, enzymes, dietary supplements, pharmaceutical compounds (Elisashvili, 2012), feed supplements (Santos et al., 2015), and flavoring agents (Jong and Birminghamn, 1993), among other uses.

According to Lindequist et al. (2005), $80-85 \%$ of all medicinal mushroom products is derived from fruiting bodies and only $15-20 \%$ is from mycelia in submerged cultivation. However, submerged cultivation is more efficient and under better control for producing medicinal biocompounds from basidiomycetes (Elisashvili, 2012; Bertéli et al., 2014; Almeida et al., 2015). The first step for submerged cultivation success is the screening of basidiomycetes that are well-adapted to the environment and capable of yielding large amounts of biotechnological bioproducts.

Basidiomycete medicinal properties originate from various cellular components and secondary metabolites that can be isolated and identified in the fruiting body, vegetative mycelia, or in the culture broth (Elisashvili, 2012). One important indicator of the medicinal properties of an organism is its antioxidant activity (Izawa and Inoue, 2004). Although numerous studies have investigated antioxidant production in medicinal mushrooms (Lindequist et al., 2005), few have examined antioxidant production of mycelial submerged cultivation. Basidiomycete strains with high mycelial biomass, exopolysaccharide production, and antioxidant activity, growing under submerged cultivation conditions, are of great industrial interest. Exopolysaccharides resulting from secondary metabolism of microorganisms are polymers excreted from the outside of the cell walls with potential applications in pharmaceutical, biochemical, and medical areas because of their specific biological activities such hepatoprotective, immunomodulatory, antiangiogenic, antiviral, and antioxidant activities (Matou et al., 2005; Borchers et al., 2008; Arena, et al., 2009). Additionally, these molecules show potential use in agriculture and in the industry (Barbosa et al., 2004). In this study, we analyzed mycelial biomass, exopolysaccharide production, and antioxidant activity of basidiomycete strains in submerged cultivation.

\section{MATERIAL AND METHODS}

\section{Biological material}

Twenty-five strains of several basidiomycetes from the Fungus Collection of the 
Laboratory of Molecular Biology of the Universidade Paranaense, including Agaricus subrufescens Peck (Agaricus blazei Murrill ss. Heinemann; Agaricus brasiliensis Wasser et al.), Lentinula edodes (Berk.) Pegler, Lentinus crinitus (L.) Fr., Pleurotus eryngii (DC.) Quél., Pleurotus ostreatus (Jacq.) P. Kumm., and Schizophyllum commune Fr., were used. For the recovery of cryopreserved fungi (Mantovani et al., 2012), the mycelium of each fungus was transferred to $20 \mathrm{~g} / \mathrm{L}$ malt extract agar medium, which had been sterilized at $121^{\circ} \mathrm{C}$ for $20 \mathrm{~min}$ and stored in the dark at $28 \pm 1^{\circ} \mathrm{C}$. Mycelium showing homogenous growth without sectioning was selected as the inoculum.

\section{Production of mycelial biomass and exopolysaccharides}

Three malt extract agar discs, measuring $5 \mathrm{~mm}$ in diameter and containing the mycelium of each strain, were transferred to $250-\mathrm{mL}$ Erlenmeyer flasks containing $30 \mathrm{~mL} 20 \mathrm{~g} / \mathrm{L}$ malt extract broth. Flasks were stored at $28 \pm 1{ }^{\circ} \mathrm{C}$ in the dark. After 10 days, another $30 \mathrm{~mL}$ malt extract broth was added to each Erlenmeyer flask. Mycelial biomass was allowed to grow for 21 days, after which it was separated by centrifugation at $2900 \mathrm{~g}$ for $15 \mathrm{~min}$ at $4^{\circ} \mathrm{C}$. The supernatant was separated (supernatant-1) and the precipitate containing mycelial biomass was washed twice with $30 \mathrm{~mL}$ ultra-purified water and again separated by centrifugation at $2900 \mathrm{~g}$ for $15 \mathrm{~min}$ at $4^{\circ} \mathrm{C}$. To determine total exopolysaccharides, $10 \mathrm{~mL}$ supernatant- 1 was mixed with $30 \mathrm{~mL}$ cold $\left(5^{\circ} \mathrm{C}\right)$ ethanol and kept at $5^{\circ} \mathrm{C}$ for $12 \mathrm{~h}$. The precipitate containing the exopolysaccharides was separated by centrifugation at $2900 \mathrm{~g}$ for $15 \mathrm{~min}$ at $4^{\circ} \mathrm{C}$. The resulting mycelial biomass and the exopolysaccharides were frozen at $-20^{\circ} \mathrm{C}$ and freeze-dried to determine dry mass. All experiments were conducted in triplicate.

\section{Antioxidant activity of mycelial biomass and exopolysaccharides}

First, $1.5 \mathrm{~mL}$ methanol was added to the freeze-dried mycelial biomass or $0.2 \mathrm{~g}$ exopolysaccharides and stored at $60^{\circ} \mathrm{C}$ for $60 \mathrm{~min}$ (Mourão et al., 2011); the mixture was centrifuged at $4400 \mathrm{~g}$ for $20 \mathrm{~min}$ at $4^{\circ} \mathrm{C}$. The supernatant was considered the raw extract. Free radical scavenging activity was determined using the 1,1-diphenyl-2-picrylhydrazyl method. For this test, $0.1 \mathrm{~mL}$ raw extract was mixed with $2.9 \mathrm{~mL} 60 \mu \mathrm{M}$ fresh 1,1-diphenyl-2-picrylhydrazyl methanolic solution. After incubation for $30 \mathrm{~min}$ at $22 \pm 2^{\circ} \mathrm{C}$, decreased absorbance at $515 \mathrm{~nm}$ was observed. All tests were repeated 3 times. The antioxidant activity was calculated relative to a standard solution of $60 \mu \mathrm{M}$ quercetin, the absorbance of which was considered to be $100 \%$ (Molyneux, 2004) and total antioxidant capacity was calculated by multiplying the percentage of antioxidant activity by the mass of the mycelial biomass or exopolysaccharide produced. The results were analyzed by variance analyses and the differences among averages determined by Scott-Knott's test $(\mathrm{P} \leq 0.05)$. Multiple regression and correlation analyses were conducted to examine associations among mycelial biomass, exopolysaccharide production, and antioxidant activity.

\section{RESULTS}

Table 1 shows the production of mycelial biomass and the antioxidant activity for the basidiomycete mycelial biomass. The mycelial biomass production was higher $(\mathrm{P} \leq 0.05)$ for Lentinus crinitus U9-1 at $1190 \pm 52 \mathrm{mg} \cdot \mathrm{L}^{-1} \cdot$ day $^{-1}$ and lower $(\mathrm{P} \leq 0.05)$ for strains of Agaricus 
subrufescens $\mathrm{U} 2-6$ and $\mathrm{U} 2-4$ with $98 \pm 8$ and $87 \pm 9 \mathrm{mg} \cdot \mathrm{L}^{-1} \cdot$ day $^{-1}$, respectively (Table 1 ). The latter showed some of the lowest results, while other strains of $A$. subrufescens showed intermediate results for mycelial biomass production, such as A. subrufescens $\mathrm{U} 2-7$, the second most productive strain with $993 \pm 45 \mathrm{mg} \cdot \mathrm{L}^{-1} \cdot \mathrm{day}^{-1}$ (Table 1 ).

Table 1. Mycelial biomass (MB), antioxidant activity (AA), and total AA of basidiomycete strains.

\begin{tabular}{|c|c|c|c|c|}
\hline Strain & Code & $\begin{array}{l}\mathrm{MB}\left(\mathrm{mg} \cdot \mathrm{L}^{-1} \cdot \text { day }^{-1} \text { of }\right. \\
\text { cultivation medium })\end{array}$ & $\begin{array}{l}\text { AA (\% Quercetin } / \mathrm{mg} \\
\text { mycelium)* }\end{array}$ & $\begin{array}{l}\text { Total AA }\left(\% \text { quercetin } \cdot \mathrm{L}^{-1} \cdot \mathrm{day}^{-1}\right. \\
\text { cultivation medium })\end{array}$ \\
\hline Agaricus subrufescens & U4-2 & $842 \pm 91^{c}$ & $11.17 \pm 1.50^{\mathrm{b}}$ & $9384 \pm 317^{\mathrm{a}}$ \\
\hline Agaricus subrufescens & $\mathrm{U} 2-7$ & $993 \pm 45^{\mathrm{b}}$ & $7.16 \pm 1.47^{\mathrm{e}}$ & $7109 \pm 335^{b}$ \\
\hline Lentinus crinitus & U9-1 & $1190 \pm 52^{\mathrm{a}}$ & $5.84 \pm 0.22^{f}$ & $6930 \pm 156^{b}$ \\
\hline Schizophyllum commune & U6-7 & $868 \pm 24^{c}$ & $7.02 \pm 0.22^{\mathrm{e}}$ & $6078 \pm 330^{c}$ \\
\hline Agaricus subrufescens & $\mathrm{U} 2-3$ & $475 \pm 12^{\mathrm{e}}$ & $11.74 \pm 1.71^{\mathrm{b}}$ & $5576 \pm 279^{d}$ \\
\hline Agaricus subrufescens & U11-2 & $487 \pm 16^{\mathrm{e}}$ & $9.85 \pm 0.28^{\mathrm{c}}$ & $4796 \pm 170^{\mathrm{e}}$ \\
\hline Agaricus subrufescens & $\mathrm{U} 7-3$ & $629 \pm 28^{d}$ & $7.24 \pm 0.10^{\mathrm{e}}$ & $4554 \pm 120^{\mathrm{e}}$ \\
\hline Agaricus subrufescens & U4-1 & $368 \pm 27^{\mathrm{f}}$ & $11.35 \pm 1.80^{\mathrm{b}}$ & $4176 \pm 98^{f}$ \\
\hline Pleurotus ostreatus & $\mathrm{U} 2-11$ & $615 \pm 38^{d}$ & $6.61 \pm 0.18^{\mathrm{f}}$ & $4065 \pm 102^{f}$ \\
\hline Pleurotus ostreatus & U2-9 & $573 \pm 21^{d}$ & $7.09 \pm 0.34^{\mathrm{e}}$ & $4062 \pm 80^{\mathrm{f}}$ \\
\hline Pleurotus ostreatus & U6-9 & $652 \pm 38^{d}$ & $6.20 \pm 0.10^{\mathrm{f}}$ & $4042 \pm 69^{f}$ \\
\hline Agaricus subrufescens & $\mathrm{U} 2-1$ & $654 \pm 74^{\mathrm{d}}$ & $5.94 \pm 0.49^{\mathrm{f}}$ & $3878 \pm 145^{\mathrm{f}}$ \\
\hline Agaricus subrufescens & $\mathrm{U} 2-2$ & $615 \pm 78^{d}$ & $6.40 \pm 0.35^{\mathrm{f}}$ & $3936 \pm 77^{\mathrm{f}}$ \\
\hline Pleurotus ostreatus & U6-8 & $651 \pm 14^{d}$ & $6.01 \pm 0.15^{\mathrm{f}}$ & $3912 \pm 95^{\mathrm{f}}$ \\
\hline Pleurotus ostreatus & U6-10 & $639 \pm 51^{d}$ & $5.96 \pm 0.26^{\mathrm{f}}$ & $3808 \pm 133^{\mathrm{f}}$ \\
\hline Agaricus subrufescens & U7-1 & $479 \pm 51^{\mathrm{f}}$ & $4.64 \pm 0.62^{g}$ & $2224 \pm 177^{g}$ \\
\hline Pleurotus eryngii & U8-11 & $548 \pm 14^{\mathrm{e}}$ & $4.02 \pm 1.11^{\mathrm{g}}$ & $2203 \pm 168^{\mathrm{g}}$ \\
\hline Lentinula edodes & U6-11 & $319 \pm 16^{\mathrm{g}}$ & $6.16 \pm 0.10^{\mathrm{f}}$ & $1965 \pm 190^{\mathrm{g}}$ \\
\hline Agaricus subrufescens & U6-16 & $105 \pm 9^{i}$ & $17.63 \pm 0.10^{\mathrm{a}}$ & $1851 \pm 255^{\mathrm{g}}$ \\
\hline Lentinula edodes & U6-12 & $369 \pm 45^{f}$ & $5.05 \pm 0.21^{\mathrm{g}}$ & $1863 \pm 184^{\mathrm{g}}$ \\
\hline Agaricus subrufescens & $\mathrm{U} 2-6$ & $98 \pm 8^{i}$ & $11.62 \pm 0.48^{b}$ & $1138 \pm 64^{\mathrm{h}}$ \\
\hline Lentinula edodes & U8-1 & $259 \pm 12^{\mathrm{h}}$ & $4.02 \pm 0.11^{\mathrm{g}}$ & $1041 \pm 122^{\mathrm{h}}$ \\
\hline Agaricus subrufescens & U4-3 & $115 \pm 16^{\mathrm{i}}$ & $8.43 \pm 0.34^{\mathrm{d}}$ & $969 \pm 163^{\mathrm{h}}$ \\
\hline Agaricus subrufescens & U4-4 & $87 \pm 9^{i}$ & $8.68 \pm 0.14^{\mathrm{d}}$ & $755 \pm 105^{\mathrm{i}}$ \\
\hline Agaricus subrufescens & $\mathrm{U} 2-4$ & $329 \pm 22^{\mathrm{g}}$ & $2.29 \pm 0.21^{\mathrm{h}}$ & $753 \pm 94^{i}$ \\
\hline
\end{tabular}

*Percentage in relation to $60 \mu \mathrm{M}$ quercetin solution. Averages indicated by the same letter do not differ statistically according to the Scott-Knott test $(\mathrm{P} \leq 0.05)$.

Higher antioxidant activity $(\mathrm{P} \leq 0.05)$ was observed for $A$. subrufescens $\mathrm{U} 6-16$ with $17.63 \pm 0.10 \%{ }_{\text {Quercetin }} / \mathrm{mg}$, but it produced only $105 \pm 9 \mathrm{mg} \cdot \mathrm{L}^{-1} \cdot \mathrm{day}^{-1}$ of mycelial biomass (Table 1). In contrast, Lentinus crinitus U9-1 showed the highest production of mycelial biomass, with antioxidant activity of just $5.84 \pm 0.22 \%_{\text {Quercetin }} / \mathrm{mg}$ (Table 1 ).

The total antioxidant activity was higher $(\mathrm{P} \leq 0.05)$ for $A$. subrufescens $\mathrm{U} 4-2$ with $9384 \pm 317 \%_{\text {Quercetin }}$ L/day. This strain was the third-highest producer of mycelial biomass $(842 \pm 91 \mathrm{mg} / \mathrm{L})$ and had the second-highest antioxidant activity $\left(11.17 \pm 1.5 \%_{\text {Queretin }} / \mathrm{mg}\right)$; thus, when combined biomass production and antioxidant activity the A. subrufescens U4-2 becomes the highest antioxidant producer (Table 1).

Table 2 shows the production of the exopolysaccharides and its antioxidant activity as well as total antioxidant activity for the basidiomycete exopolysaccharides. Exopolysaccharide production was higher $(\mathrm{P} \leq 0.05)$ for the A. subrufescens $\mathrm{U} 11-2, \mathrm{U} 7-3, \mathrm{U} 2-4, \mathrm{U} 2-2$, and U2-1 strains, ranging from $18.96 \pm 0.15$ to $20.97 \pm 2.10 \mathrm{mg} \cdot \mathrm{L}^{-1} \cdot$ day $^{-1}$ (Table 2). The highest $(\mathrm{P} \leq 0.05)$ exopolysaccharide production with relatively higher $(\mathrm{P} \leq 0.05)$ antioxidant activity was observed for A. subrufescens, emphasizing the therapeutic potential of this basidiomycete. The total antioxidant activity of exopolysaccharides was the highest $(\mathrm{P} \leq 0.05)$ for $A$. subrufescens U11-2 with $347 \pm 28 \%_{\text {Quercetin }}$ L/day (Table 2). 
Table 2. Exopolysaccharides (EPS), antioxidant activity (AA), and total AA of basidiomycete strains.

\begin{tabular}{|c|c|c|c|c|}
\hline Strain & Code & $\begin{array}{l}\text { EPS }\left(\mathrm{mg} \cdot \mathrm{L}^{-1} \cdot \text { day }^{-1}\right. \\
\text { cultivation medium) }\end{array}$ & $\begin{array}{l}\text { AA }(\% \text { Quercetin } / \mathrm{mg} \\
\text { mycelium })^{*}\end{array}$ & $\begin{array}{l}\text { Total AA ( } \% \text { Quercetin/L } \\
\text { cultivation medium) }\end{array}$ \\
\hline Agaricus subrufescens & U11-2 & $19.21 \pm 1.30^{\mathrm{a}}$ & $18.08 \pm 1.23^{\mathrm{a}}$ & $347 \pm 28^{\mathrm{a}}$ \\
\hline Agaricus subrufescens & U7-3 & $18.96 \pm 0.15^{\mathrm{a}}$ & $14.80 \pm 1.57^{\mathrm{b}}$ & $273 \pm 35^{\mathrm{b}}$ \\
\hline Agaricus subrufescens & $\mathrm{U} 2-4$ & $19.06 \pm 0.94^{\mathrm{a}}$ & $11.23 \pm 0.17^{\mathrm{d}}$ & $217 \pm 86^{\mathrm{b}}$ \\
\hline Agaricus subrufescens & $\mathrm{U} 2-2$ & $20.97 \pm 2.10^{\mathrm{a}}$ & $13.11 \pm 0.36^{\mathrm{c}}$ & $275 \pm 20^{b}$ \\
\hline Agaricus subrufescens & $\mathrm{U} 4-2$ & $18.16 \pm 0.36^{\mathrm{b}}$ & $12.86 \pm 0.23^{\mathrm{c}}$ & $236 \pm 58^{b}$ \\
\hline Agaricus subrufescens & $\mathrm{U} 2-3$ & $15.13 \pm 0.87^{\mathrm{c}}$ & $17.47 \pm 1.66^{\mathrm{a}}$ & $264 \pm 28^{b}$ \\
\hline Agaricus subrufescens & U4-1 & $17.96 \pm 0.39^{b}$ & $12.74 \pm 0.04^{\mathrm{c}}$ & $228 \pm 52^{\mathrm{b}}$ \\
\hline Agaricus subrufescens & $\mathrm{U} 2-1$ & $19.63 \pm 1.93^{\mathrm{a}}$ & $11.33 \pm 0.32^{\mathrm{d}}$ & $222 \pm 25^{\mathrm{b}}$ \\
\hline Agaricus subrufescens & U7-1 & $12.60 \pm 1.06^{\mathrm{d}}$ & $15.35 \pm 1.76^{\mathrm{b}}$ & $193 \pm 17^{\mathrm{c}}$ \\
\hline Agaricus subrufescens & $\mathrm{U} 2-6$ & $18.13 \pm 0.66^{\mathrm{b}}$ & $9.35 \pm 0.04^{\mathrm{e}}$ & $175 \pm 29^{c}$ \\
\hline Agaricus subrufescens & U4-3 & $10.08 \pm 0.99^{\mathrm{d}}$ & $15.85 \pm 0.99^{b}$ & $159 \pm 38^{\mathrm{c}}$ \\
\hline Agaricus subrufescens & $\mathrm{U} 2-7$ & $10.12 \pm 1.99^{d}$ & $11.07 \pm 0.52^{\mathrm{d}}$ & $112 \pm 10^{\mathrm{d}}$ \\
\hline Agaricus subrufescens & U4-4 & $3.49 \pm 0.08^{\mathrm{g}}$ & $15.08 \pm 0.45^{\mathrm{b}}$ & $53 \pm 2^{\mathrm{e}}$ \\
\hline Agaricus subrufescens & U6-16 & $3.41 \pm 0.07^{\mathrm{g}}$ & $14.93 \pm 0.41^{b}$ & $51 \pm 1^{\mathrm{e}}$ \\
\hline Pleurotus eryngii & U8-11 & $7.01 \pm 0.76^{\mathrm{e}}$ & $7.32 \pm 0.06^{\mathrm{f}}$ & $51 \pm 4^{\mathrm{e}}$ \\
\hline Pleurotus ostreatus & $\mathrm{U} 2-9$ & $6.56 \pm 0.33^{\mathrm{e}}$ & $7.14 \pm 0.05^{f}$ & $47 \pm 6^{\mathrm{e}}$ \\
\hline Pleurotus ostreatus & U6-9 & $5.51 \pm 0.28^{\mathrm{f}}$ & $7.41 \pm 0.06^{\mathrm{f}}$ & $41 \pm 3^{\mathrm{f}}$ \\
\hline Pleurotus ostreatus & U6-8 & $5.47 \pm 0.16^{\mathrm{f}}$ & $7.44 \pm 0.08^{\mathrm{f}}$ & $41 \pm 2^{\mathrm{f}}$ \\
\hline Schizophyllum commune & U6-7 & $3.77 \pm 1.70^{\mathrm{g}}$ & $11.09 \pm 0.19^{\mathrm{d}}$ & $42 \pm 1^{\mathrm{f}}$ \\
\hline Lentinula edodes & U8-1 & $3.10 \pm 0.34^{\mathrm{g}}$ & $7.17 \pm 0.17^{\mathrm{f}}$ & $22 \pm 3^{g}$ \\
\hline Lentinus crinitus & U9-1 & $3.20 \pm 0.04^{\mathrm{g}}$ & $7.25 \pm 0.28^{f}$ & $23 \pm 1^{g}$ \\
\hline Pleurotus ostreatus & U6-10 & $3.05 \pm 0.19^{\mathrm{g}}$ & $7.28 \pm 0.15^{f}$ & $22 \pm 1^{g}$ \\
\hline Pleurotus ostreatus & $\mathrm{U} 2-11$ & $2.98 \pm 0.25^{\mathrm{g}}$ & $6.90 \pm 0.68^{f}$ & $20 \pm 1^{g}$ \\
\hline Lentinula edodes & U6-12 & $2.51 \pm 0.30^{\mathrm{g}}$ & $6.95 \pm 0.29^{f}$ & $17 \pm 2^{\mathrm{g}}$ \\
\hline Lentinula edodes & U6-11 & $1.95 \pm 0.22^{\mathrm{h}}$ & $7.41 \pm 0.01^{\mathrm{f}}$ & $14 \pm 1^{\mathrm{h}}$ \\
\hline
\end{tabular}

*Percentage in relation to $60 \mu \mathrm{M}$ quercetin solution. Averages indicated by the same letter do not differ statistically according to the Scott-Knott test $(\mathrm{P} \leq 0.05)$.

The mycelial biomass, exopolysaccharide production, and the respective antioxidant activity showed high variability among species and even among different strains of the same species. Considering only the strains of $A$. subrufescens, the mycelial biomass production varied by approximately 11 -fold, the antioxidant activity of the mycelial biomass varied by approximately 8 -fold, the exopolysaccharide production varied by approximately 6 -fold, and the antioxidant activity varied by approximately 2 -fold. In addition, no significant correlation was found between mycelial biomass or exopolysaccharide production and its antioxidant activity for the strains, but values depended on each species and among strains of the same species.

\section{DISCUSSION}

Kirsch et al. (2011) cultivated L. citrinus in medium containing $0.5 \%$ soluble starch and $0.2 \%$ gelatin and obtained $1150 \mathrm{mg} \cdot \mathrm{L}^{-1} \cdot \mathrm{day}^{-1}$ mycelial biomass. In our study, a similar result was found for L. crinitus $\left(1190 \mathrm{mg} \cdot \mathrm{L}^{-1} \cdot \mathrm{day}^{-1}\right.$; Table 1). Elisashvili (2012) reported mycelial biomass production in submerged cultivation in the range of $5300-12,700 \mathrm{mg} / \mathrm{L}$ at different cultivation times for different basidiomycetes. Although numerous variables affect mycelial biomass production, strain type appeared to be the most important factor in cultivation (Mshandete and Mgonja, 2009). Therefore, L. crinitus U9-1 is an excellent choice for biotechnological processes involving mycelial biomass production.

All strains evaluated produced exopolysaccharides. Fungal exopolysaccharides function in adhesion to the substrate, immobilization of extracellular enzymes, prevention of hyphal dehydration, and storage of excess nutrients, as well as participate in lignin degradation, a widespread process among basidiomycetes (Elisashvili, 2012). The highest exopolysaccharide 
production was obtained for strains of $A$. subrufescens, which reached $20.97 \mathrm{mg} \cdot \mathrm{L}^{-1} \cdot$ day $^{-1}$. Lin and Yang (2006) reported an exopolysaccharide yield of $35.85 \mathrm{mg} \cdot \mathrm{L}^{-1} \cdot \mathrm{day}^{-1}$ for $A$. subrufescens grown in an optimized cultivation medium with malt extract, yeast extract, and peptone at $105 \mathrm{rpm}$ for 7 days at $27^{\circ} \mathrm{C}$. Fan et al. (2007) cultivated A. subrufescens under optimized conditions in medium containing glucose, yeast extract, $\mathrm{K}_{2} \mathrm{HPO}_{4}$, and $\mathrm{MgSO}_{4}$ for 7 days, without agitation, at $30^{\circ} \mathrm{C}$ and obtained $32.45 \mathrm{mg} \cdot \mathrm{L}^{-1} \cdot$ day $^{-1}$. Shu and $\mathrm{Xu}(2007)$ produced $A$. subrufescens in medium containing glucose, yeast extract, malt extract, polypeptone, $\mathrm{K}_{2} \mathrm{HPO}_{4}$, $\mathrm{MgSO}_{4}$, and vitamin $\mathrm{B}_{1}$ for 24 days at $28^{\circ} \mathrm{C}$, with aeration of 0.15 volume per volume per minute, and obtained $98.33 \mathrm{mg} \cdot \mathrm{L}^{-1} \cdot \mathrm{day}^{-1}$ exopolysaccharides. In our study, the exopolysaccharide production from strains of $A$. subrufescens varied from $3.41-20.97 \mathrm{mg} \cdot \mathrm{L}^{-1} \cdot \mathrm{day}^{-1}$, with a possible greater increase in exopolysaccharide production after the optimization of the cultivation conditions.

Lin and Chen (2007) studied the factors affecting the production of mycelial biomass and exopolysaccharides in submerged cultivation of Antrodia cinnamomea. They observed that high mycelial biomass production was not a determining factor for a high exopolysaccharide yield. In our study, no significant correlation was found between mycelial biomass and exopolysaccharide production. This appears to be a consensus in the literature and is in accordance with the findings of Maziero et al. (1999) who evaluated 48 native Brazilian basidiomycete strains and 8 commercial ones but found no relationship between mycelial biomass and exopolysaccharide production in submerged cultivation.

Agaricus subrufescens showed the highest antioxidant activity and the highest production of exopolysaccharides among the other strains evaluated (Table 2). Exopolysaccharides of $A$. subrufescens included glucoproteins, mainly $\beta$-D-glucans, which are primarily responsible for the biological activities of this fungus (Chen and Seviour, 2007). Ker et al. (2005) studied the antioxidant activity of 5 polysaccharide fractions extracted from $A$. subrufescens mycelium in submerged cultivation and associated the potent antioxidant effect with the high number of hydroxyl groups in the polysaccharide and the low content of polysaccharide-protein complexes. Izawa and Inoue (2004) suggested that $A$. subrufescens extracts contain a complex mixture of antioxidants and other substances that may act synergistically to reduce free radicals. The high free radical scavenging capacity of A. subrufescens reported in our study is in accordance with the results of previous studies. In addition, it is possible to increase the production of antioxidant molecules for A. subrufescens by studying several culture conditions such as temperature, carbon, and nitrogen sources, among others.

Mycelial submerged cultivation can provide a faster route for antioxidant and exopolysaccharide production in basidiomycetes. No significant correlation was found between mycelial biomass or exopolysaccharide production and antioxidant activity for the basidiomycete strains studied. The strains recommended for the production of mycelial biomass and for high total antioxidant activity include $L$. crinitus U9-1 and A. subrufescens U4-2 and U2-7. This is the first study to describe the antioxidant activity of L. crinitus. For antioxidants from exopolysaccharides, A. subrufescens, mainly the strain U11-2, is recommended. We observed high variability for the production of mycelial biomass, exopolysaccharides, and antioxidant activity among different species and even among strains of the same species, making it essential to evaluate the total antioxidant activity to identify strains with biotechnological potential. 


\section{Conflicts of interest}

The authors declare no conflict of interest.

\section{ACKNOWLEDGMENTS}

Research supported by Coordenação de Aperfeiçoamento de Pessoal de Nível Superior (CAPES), Paranaense University, and the Postgraduate Program in Biotechnology Applied to Agriculture.

\section{REFERENCES}

Almeida SM, Umeo SH, Marcante RC, Yokota ME, et al. (2015). Iron bioaccumulation in mycelium of Pleurotus ostreatus. Braz. J. Microbiol. 46: 195-200.

Arena A, Gugliandolo C, Stassi G, Pavone B, et al. (2009). An exopolysaccharide produced by Geobacillus thermodenitrificans strain B3-72: antiviral activity on immunocompetent cells. Immunol. Lett. 123: 132-137.

Barbosa AM, Cunha PDT, Pigatto MM and Silva MLC (2004). Produção e aplicações de exopolissacarídeos fúngicos. Semina Cienc. Exatas Tecnol. 25: 29-42.

Bertéli MB, Umeo SH, Bertéli A, Valle JS, et al. (2014). Mycelial antineoplastic activity of Agaricus blazei. World J. Microbiol. Biotechnol. 30: 2307-2313.

Blackwell M (2011). The fungi: 1, 2, 3 ... 5.1 million species? Am. J. Bot. 98: 426-438.

Borchers AT, Krishnamurthy A, Keen CL, Meyers FJ, et al. (2008). The immune biology of mushrooms. Exp. Biol. Med. 233: 259-276.

Chen J and Seviour R (2007). Medicinal importance of fungal b-(1-->3), (1-->6)-glucans. Mycol. Res. 111: 635-652.

Elisashvili V (2012). Submerged cultivation of medicinal mushrooms: bioprocesses and products (review). Int. J. Med. Mushrooms 14: 211-239.

Fan L, Soccol AT, Pandey A and Soccol CR (2007). Effect of nutritional and environmental conditions on the production of exopolysaccharide of Agaricus brasiliensis by submerged fermentation and its antitumor activity. Lebenson Wiss. Technol. 40: 30-35.

Izawa S and Inoue YA (2004). A screening system for antioxidants using thioredoxin-deficient yeast: discovery of thermostable antioxidant activity from Agaricus blazei Murill. Appl. Microbiol. Biotechnol. 64: 537-542.

Jong SC and Birmingham JM (1993). Mushrooms as a source of natural flavour and aroma compounds. In: Mushroom Biology and Mushroom Products (Chang ST, Buswell JA and Chiu SW, eds.). The Chinese University, Hong Kong, 345-366.

Ker YB, Chen KC, Chyau CC, Chen CC, et al. (2005). Antioxidant capability of polysaccharides fractionated from submerge-cultured Agaricus blazei mycelia. J. Agric. Food Chem. 53: 7052-7058.

Kirsch L de S, Pinto AC, Porto TS, Porto AL, et al. (2011). The influence of different submerged cultivation conditions on mycelial biomass and protease production by Lentinus citrinus Walleyn et Rammeloo DPUA 1535 (Agaricomycetideae). Int. J. Med. Mushrooms 13: 185-192.

Li Y (2012). Present development situation and tendency of edible mushroom industry in China. In: Proceedings of the Congress of the International Society for Mushroom Science, Beijing, 3-9.

Lin ES and Chen YH (2007). Factors affecting mycelial biomass and exopolysaccharide production in submerged cultivation of Antrodia cinnamomea using complex media. Bioresour. Technol. 98: 2511-2517.

Lin JH and Yang SS (2006). Mycelium and polysaccharide production of Agaricus blazei Murrill by submerged fermentation. J. Microbiol. Immunol. Infect. 39: 98-108.

Lindequist U, Niedermeyer TH and Jülich WD (2005). The pharmacological potential of mushrooms. Evid. Based Complement. Alternat. Med. 2: 285-299.

Mantovani TR, Tanaka HS, Umeo SH, Zaghi Junior LL, et al. (2012). Cryopreservation at -20 and $-70^{\circ} \mathrm{C}$ of Pleurotus ostreatus on grains. Indian J. Microbiol. 52: 484-488.

Matou S, Colliec-Jouault S, Galy-Fauroux I, Ratiskol J, et al. (2005). Effect of an oversulfated exopolysaccharide on angiogenesis induced by fibroblast growth factor-2 or vascular endothelial growth factor in vitro. Biochem. Pharmacol. 69: 751-759.

Maziero R, Cavazzoni V and Bononi VLR (1999). Screening of Basidiomycetes for the production of exopolysaccharide and biomass in submerged culture. Rev. Microbiol. 30: 77-84.

Genetics and Molecular Research 14 (3): 9907-9914 (2015)

CFUNPEC-RP www.funpecrp.com.br 
Molyneux P (2004). The use of the stable free radical diphenylpicrylhydrazyl (DPPH) for estimating antioxidant activity. Songklanakarin J. Sci. Technol. 26: 211-219.

Mourão F, Harue Umeo S, Seiko Takemura O, Andrea Linde G, et al. (2011). Antioxidant activity of Agaricus brasiliensis basidiocarps on different maturation phases. Braz. J. Microbiol. 42: 197-202.

Mshandete AM and Mgonja JR (2009). Submerged liquid fermentation of some Tanzanian basidiomycetes for the production of mycelial biomass, exopolysaccharides and mycelium protein using wastes peels media. J. Agric. Biol. Sci. 4: 1-13.

Santos MP, Marcante RC, Santana TT, Tanaka HS, et al. (2015). Oyster culinary-medicinal mushroom, Pleurotus ostreatus (Higher Basidiomycetes), growth in grain-based diet improves broiler chicken production. Int. J. Med. Mushrooms 17: 169-178.

Shu $\mathrm{CH}$ and $\mathrm{Xu} \mathrm{CJ}$ (2007). Medium optimization for producing bioactive exopolysaccharides by Agaricus brasiliensis $\mathrm{S}$. Wasser et al. (=A. blazei Murrill ss. Heinem) in submerged culture. Food Technol. Biotechnol. 45: 327-333. 